\title{
Juventud, conversión religiosa y etnicidad en los Andes del Noroeste Argentino
}

Claudia Lozano B. ${ }^{1}$

\section{RESUMEN}

En este artículo mostramos que la actividad de las misiones católicas y bautistas en la quebrada de Humahuaca, en la provincia argentina de Jujuy, ha dado lugar a la formación de una arena religiosa múltiple, en la cual las nuevas generaciones, jóvenes estudiantes y trabajadores, optan por participar de una u otra organización religiosa. En el contexto de las congregaciones, los estereotipos culturales que vinculan al mundo indígena y sus prácticas culturales al atraso, al descontrol y a la violencia familiar son cuestionados y renegociados.

Palabras claves: Noroeste Argentino - etnicidad - movimientos religiosos - misiones - juventud.

\section{ABSTRACT}

This paper shows that in Quebrada de Humahuaca (Jujuy, Argentina), Catholic and Baptist Missions' activities, gave place to a multiple religious background, in which new generations, students and workers, choose to take part in one of these religious organizations. In these congregations, cultural stereotypes linking indigenous world and their cultural practices to backwardness, lack of control and familiar violence, are questioned and negotiated.

Key words: Northwest Argentina - ethnicity - religious movements - missions - youth.

\section{Introducción}

Durante la tarde de la víspera de la Fiesta Patronal de Ronque, una localidad rural de los Andes argentinos, ubicada a $3.500 \mathrm{~m} . \mathrm{snm}$ y a $160 \mathrm{~km}$ de la frontera boliviana, varios vecinos trabajaban en la construcción del Salón de Fiestas Comunitario. Un grupo de jóvenes conversaba con "los viejos" de La Comisión Protemplo con el objetivo de obtener autorización para invitar a una banda musical boliviana difundida por la radio para que animara la fiesta. En la cocina del salón Lucía y María seguían con atención la discusión y discu-

1 CEIL / CONICET, Wilhelmstr. 5, 58456 Witten, Alemania. Email: clozan@aol.com rrían sobre los cambios en las "costumbres de estilo" que imponen los jóvenes de hoy. Pese al costo y a los posibles desbordes, ${ }^{2}$ los abuelos aceptaron invitar a los músicos tarijeños. A cambio de ello esperaban que los jóvenes trabajaran en sus sembradíos, los apoyaran en sus componendas electorales y en la administración de los recursos comunes.

A diferencia de ellos, en las localidades urbanas de la quebrada de Humahuaca, las "barras", "patotas" o grupos de jóvenes se reúnen en las esquinas, pasan horas mirando y conversando con amigas, toman cerveza y discuten de música. Van al "vicio" o locales de juegos electrónicos, donde además miran videos. Las noches del fin de semana asisten a bailes específicamente organizados para ellos, donde también cometen desbordes. El papá de uno de ellos comentaba “... prefiero los bailes del campo. Allí las mujeres son 'avanzadas' y nosotros olvidamos las diferencias (étnicas, de clase)...”.

El comportamiento de los jóvenes es algo controvertido y todas las culturas tienen algo que decirnos al respecto. En los Andes del Noroeste de Argentina, los miembros de la Iglesia Católica y de la Iglesia Bautista de la ciudad de Humahuaca, ubicada en la provincia argentina de Jujuy, ponen a disposición de los jóvenes modelos de conducta alternativos a los imperantes en la sociedad local (Figura 1).

La mayor parte de los jóvenes que vivían en Humahuaca estaban interesados en el éxito económico, en la compra de ropa, autos o equipos de música y de computación; vivían sus vidas como si la crisis económica no existiera; no se interesaban por la actividad política ni por la cultura indígena local. Trabajaban para sus padres en las

\footnotetext{
2 La noción de "desborde" refiere al descontrol festivo: gritos, saltos, lanzamiento de botellas de cerveza, etc.
} 


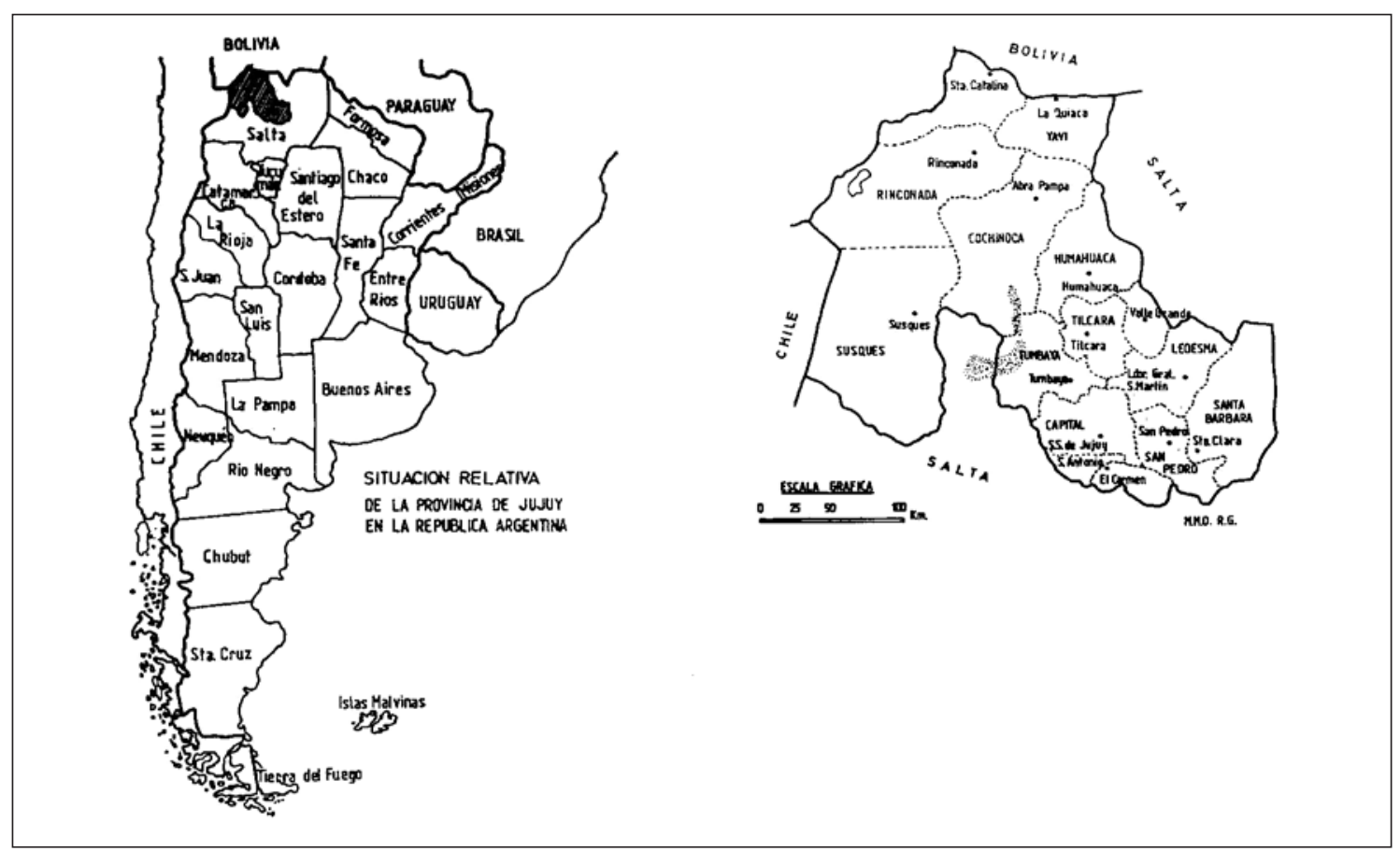

Figura 1. Mapa que ilustra la situación relativa de la provincia de Jujuy en la República Argentina, y detalle de la misma.

localidades y, tan pronto como podían, migraban en busca de trabajo a otras regiones de la provincia o del país o intentaban estudiar en la universidad. Salían por las noches con amigos, bebían, establecían relaciones con las jóvenes, pero no mostraban interés por el matrimonio.

Para retenerlos en la región, la Iglesia Católica les proponía integrarse a las actividades de promoción social. La participación en cursos y encuentros debería contribuir a capacitar a los jóvenes con vistas a que colaboraran en la gestión de programas sociales destinados al cuidado de la salud, al saneamiento ambiental, al desarrollo de pequeñas empresas y de redes de comunicación social, así como a la recuperación de la memoria histórica.

A diferencia de ellos, los misioneros y los pastores bautistas criticaban las prácticas "cristo-paganas" presentes en la región, que estimulan el consumo de alcohol, el machismo y el clientelismo político. A este modelo de acción social oponían un modelo basado en la fe respecto de la intervención de la voluntad divina en el mundo y la autonomía de la religión respecto del Estado. Para que la voluntad divina operara en favor de las personas, las personas debían convertirse, buscar oportunidades de estudio y de trabajo dentro y fuera de la región, ahorrar dinero y colaborar con las labores hogareñas y de la congregación.

¿Cómo es posible que los jóvenes no se interesen por discursos y prácticas religiosas que les proponen integrarse y mejorar sus condiciones de vida? ¿Cómo es posible que los jóvenes no se interesen por unos discursos y unas prácticas religiosas que les garantizan prosperidad y autonomía? ¿Cómo entienden ellos los mensajes de las Iglesias y qué rechazan? ¿Quiénes son los jóvenes que sí comprenden los mensajes de las Iglesias y se comprometen?

\section{Opciones religiosas y etnicidad}

En la década del '90, los estudios sobre los movimientos religiosos en América Latina permitieron romper con los prejuicios existentes en las ciencias sociales respecto de la relación existente entre religión, pobreza y enajenación. Estos estudios mostraron que la práctica y los discursos religiosos, lejos de desvincular a las personas de sus realidades mundanas, les ofrecen estrategias y tácticas para sobrevivir situaciones de estrés 
emocional vinculadas a la pobreza y a la violencia (Brusco 1995; Burdick 1992 y 1993; Forni 1989; Ströbele-Gregor 1989; Stoll y Brunett 1993). Sin embargo, el interés y el carácter pragmático de la actividad religiosa en América Latina no constituían algo nuevo. La novedad la constituía la expansión creciente de los grupos protestantes en un continente masivamente católico. Estudios de caso detallados mostraron que, especialmente en aquellos lugares, en los cuales la Iglesia Católica está vinculada al liderazgo político de las clases altas o medias, los grupos protestantes generan un liderazgo basado en la autonomía frente al Estado y a la política y centrado en la participación de trabajadores pobres y marginales en congregaciones religiosas (Burdick 1993; Irlan 1992). En el contexto de un mundo globalizado, en el cual las estructuras de autoridad han sido fragmentadas y las personas buscan salidas en un medio hostil, los grupos protestantes constituyen una alternativa frente a instituciones jerárquicas y centralizadas (Stoll y Brunett 1993). El fuerte contenido religioso de los discursos y de las prácticas protestantes es aquello que permite a grupos específicos, mujeres, jóvenes o indígenas con escasos niveles educativos realizar rupturas con discursos y prácticas dominantes. Esta ruptura religiosa permite gestar espacios de intercambio alternativos en los cuales la educación escolar, el consumo, el control y la agresividad masculinas no son valores dados, sino valores que pueden ser contestados y reelaborados en términos de la conversión individual y colectiva (Brusco 1995; Ströble-Gregor 1989).

La población de la quebrada de Humahuaca no imagina al mundo contemporáneo sin la intervención de las misiones católicas y protestantes. Pero tampoco imaginan la vida sin la continuidad de las prácticas religiosas conocidas en el lenguaje popular como "las costumbres de estilo" o "el estilo". El estilo particular de los koyas refiere a un conjunto de significados culturales implícitos en las prácticas cotidianas de la población humahuaqueña. Tratar a las diferencias (religiosas o culturales) como construcciones de significados explícitas, deja de lado el hecho de que la participación en una nueva comunidad de prácticas exige la desarticulación de las relaciones y de las formas de vida previas, en las cuales las identidades personales y colectivas tenían sentido. ¿Hasta qué punto las personas están dispuestas a ello?
La etnografía amplia y detallada ${ }^{3}$ permite revelar que la supuesta necesidad de ruptura con articulaciones de relaciones y de identidades previas (parentesco, compadrazgo, sistemas de ayuda vecinales), que las personas tienen que mostrar hacia afuera, no implican necesariamente suprimir las continuidades en prácticas no discursivas, como, por ejemplo, los conocimientos y técnicas implícitos en las prácticas de conformación de pareja, crianza de los hijos, etc. (Harris y BouysseCassagne 1988; Harvey 1993; Platt 1976 y 1997). ${ }^{4}$ Estos no son entendidos como prácticas religiosas y culturales, ni en los modelos de acción religiosa, ni en los modelos de análisis sociológicos que entienden a la cultura, a la religión y a la identidad como fácilmente accesible e intercambiable.

Considerar a la identidad y a la diferencia como procesos complejos de construcción de relaciones significativas en circuitos múltiples de relaciones en las cuales las personas se definen a sí mismas y a los otros, permitirá dar cuenta cómo discursos, prácticas, símbolos y valores transnacionales (universales o globales) promovidos por las misiones, adquieren un carácter alternativo, contestado cuando son enlazados a las realidades locales (Comaroff y Comaroff 1993). Los misioneros que llegaron a los Andes del Noroeste Argentino fueron exitosos. Los indígenas se transformaron en cristianos. Sin embargo, las críticas de los misioneros a la forma particular, en la cual la población local, los koyas insertan sus mensajes en sus pensamientos y formas de vida contemporáneas, nos muestra que los indígenas intervienen

3 El trabajo de campo que originó este artículo fue realizado durante tres estadías prolongadas (de seis meses cada una) en 1993, 1995 y 1997. Estudié de forma detallada tres casos de organización para la práctica religiosa, la comunidad rural de Ronque y los grupos religiosos católicos de Humahuaca; la Congregación Bautista Conservadora y la Congregación Bautista Renovada de Humahuaca. Conforme al censo de 1991, habitaban en Humahuaca 6.000 personas. En la localidad de Ronque las personas habitaban en 16 unidades domésticas y la población estable estimada es de 60 personas.

4 Los estudios de estos autores realizados en los Andes Centrales permiten comprobar dos cuestiones. En primer lugar, las continuidades culturales y religiosas existentes entre la población que vive en Perú y en Bolivia. En segundo lugar, los indígenas argentinos, al igual que los bolivianos y los peruanos adaptan los discursos religiosos cristianos a sus cosmovisiones previas. 
activamente en los procesos de cambio religioso, generando significados alternativos respecto a los propuestos por las misiones. Este aspecto de la transformación de la propia actividad misional ha tendido a permanecer oculto en los estudios sobre movimientos religiosos.

Específicamente, los jóvenes con raíces indígenas, católicos y bautistas, buscan adaptarse, negociar y contestar a las prácticas y a los discursos que de forma explícita o implícita tienden a segregarlos y a marginarlos (Lozano 2001). Identificarse plenamente con la comunidad y las costumbres de sus ancestros y resistir toda transformación o diferencia los llevaría al aislamiento. $\mathrm{Ni}$ sus padres ni sus abuelos ven la posibilidad de producir y reproducir la vida con referencia a un único contexto, el de las relaciones con los parientes, con la comunidad y con la cultura local. Ellos forman parte también de circuitos de relaciones vinculados al Estado y al mercado nacional y global en Argentina (Göbel 1999; Isla 1992; Merlino y Rabey 1993). ${ }^{5}$

Estos procesos han generado efectos complejos, ya que en la medida que participan y aprenden las convenciones sociales apropiadas para conducirse en la escuela, en el mercado de trabajo, en las instituciones del Estado y en las iglesias, adquieren flexibilidad y sus percepciones sobre sus habilidades cambian. Sin embargo, adquirir una mayor habilidad para hablar y para ser escuchado en la iglesia y otras instituciones, no necesariamente permite trascender las desigualdades. $\mathrm{Ni}$ ellos ni sus vecinos de las localidades ni otros grupos sociales ven en un koya o indígena, católico o bautista, un referente asociado al orden familiar, al desarrollo empresarial y al bienestar. Por el contrario, la identificación de una persona con formas de vida indígena está asociada al trabajo campesino de los ancianos y al trabajo industrial y doméstico asalariado de varones y de mujeres jóvenes desarraigados y empobrecidos. Estas formas de simbolizar las diferencias y las identidades étnicas, en lugar de romper con prácticas establecidas, las reproduce. Ello sitúa a los jóvenes en una posición compleja en relación con la co-

5 Coincidimos con estos autores en que la intervención del Estado-nación en las localidades y en los hogares es problemática y tiende a ser permanentemente cuestionada por los pobladores. munidad de origen y a la capacidad de un discurso y unas prácticas religiosas de generar alternativas para quienes son constantemente discriminados. En la medida que ellos adquieren competencia práctica para manejar el nuevo discurso y las prácticas, rompen con la comunidad de prácticas y creencias de origen, pero al hacerlo rompen también con el poder mismo de la religión para trascender las diferencias sociales en el marco de una comunidad eclesial.

Para comprender las opciones religiosas de los jóvenes de los Andes es necesario, entonces, estudiar y analizar los efectos múltiples de la participación de los jóvenes en las Comunidades Eclesiales de Base (CEBs) católicas y en las congregaciones bautistas. Si tenemos en cuenta el conjunto de opciones para la práctica religiosa que los jóvenes encuentran en Humahuaca, del cual el catolicismo y las CEBs constituyen sólo una parte, podremos mostrar qué problemas concretos pueden resolver los jóvenes en las CEBs, quiénes realmente los resuelven, quiénes no y recurren a otras instituciones religiosas o de otro tipo. Esto me lleva a dar cuenta de la existencia de diversos circuitos comunicativos que constituyen la arena religiosa e ideológica local, en la cual los jóvenes se mueven sin pertenecer de forma exclusiva a una de las versiones religiosas institucionalizadas. Por el contrario, los jóvenes tienden a interactuar en una serie de circuitos donde encuentran discursos y prácticas religiosas e ideológicas superpuestas, más o menos formalizadas e institucionalizadas. Al moverse en estos circuitos utilizan simultáneamente el conjunto de opciones disponibles. ${ }^{6}$

6 Pensar que los sujetos participan simultáneamente de diversos circuitos, nos permite ver que la participación en las CEBs o en alguna otra institución religiosa no se relaciona exclusivamente con la tradición indígena automáticamente aceptada, o es el resultado de la elección de un consumidor libre de lazos que busca oportunidades. Desde la perspectiva de los actores involucrados, la opción religiosa se relaciona a las creencias y experiencias religiosas previas, a las redes sociales de las que participan, a los procesos complejos de constitución de la identidad personal y de relaciones y con la habilidad de un discurso religioso específico para resolver los problemas concretos que estos procesos plantean. Por ello para dar cuenta de qué es aquello que los jóvenes encuentran en el catolicismo debemos indagar sobre la habilidad de cada versión del catolicismo para resolver conflictos en contraposición a otras. 
En lo que sigue ofreceremos al lector una descripción breve de las opciones religiosas disponibles en la ciudad de Humahuaca. Posteriormente, haremos un análisis de las narrativas de los jóvenes sobre sus experiencias de participación en instituciones religiosas en la región. El análisis de las narrativas nos permitirá dar cuenta del significado que diversos agrupamientos de jóvenes le otorgan a la participación en instituciones religiosas por un lado y al significado que adquiere la relación entre etnicidad y porvenir en un discurso y unas prácticas religiosas específicas, por otro.

\section{La arena religiosa humahuaqueña}

En Humahuaca encontramos varios discursos y prácticas religiosas católicas y bautistas institucionales y no institucionalizadas. Estos discursos y prácticas fueron propagados por los misioneros que llegaron a la región, a lo largo de cinco siglos para convertir a los indígenas en cristianos. Sin embargo, los indígenas, aun cuando adoptaron el mensaje cristiano, hicieron adaptaciones acordes a un discurso y a unas prácticas religiosas reconocidas como las "costumbres de estilo" de los koyas.

\section{Las misiones católicas}

En la quebrada de Humahuaca los misioneros participaron activamente de los procesos de transformación de la cultura y de las sociedades indígenas. La actividad misional es multifacética y abarca un amplio rango de actividades destinadas a convertir a los indígenas al cristianismo. Los primeros misioneros jesuitas llegaron a la región en 1493 con los conquistadores. Su misión consistía en sustituir los cultos religiosos paganos por el culto católico. Para ello agruparon a los indígenas en Hermandades o Cofradías, destinadas a organizar las celebraciones del calendario católico y a construir iglesias y capillas en las localidades. Los jesuitas abandonaron la región en 1776 y desde entonces y hasta la llegada de los misioneros redentoristas en 1883 , la vida religiosa local quedó en manos de los miembros indígenas de las cofradías. Los misioneros redentoristas y posteriormente los misioneros del Verbo Divino (1935), trajeron el modelo de adoctrinamiento religioso del catolicismo románico. Este se basaba en la educación catequística y en la instauración del culto al Sagrado Corazón de Jesús y a la Virgen María (Vergara 1942).
El objetivo de la actividad misional fue purificar la actividad religiosa desarrollada por los cofrades. ${ }^{7}$ Los misioneros establecieron relaciones estrechas con las mujeres de la elite local. ${ }^{8}$ Los hombres y las mujeres mayores que conocieron estas épocas y los propios sacerdotes recuerdan que se trataba de una religiosidad rígida y moralizante, basada en el misterio y en el temor frente a la divinidad. La autoridad religiosa estaba centrada en el Papa y en sus representantes locales, los obispos y los sacerdotes. Estos seres poseían el conocimiento de la doctrina, del cual se derivaba su carácter sagrado. La actitud de temor frente al contacto con lo sagrado era transmitida en los cursos de doctrina dominicales. Allí los niños aprendían los misterios de la creación y las oraciones. En esta visión, la vida del ser humano se asemejaba a un camino de sufrimientos hacia la muerte y el devenir hacia una vida de contemplación eterna. Soportar el destino terrenal era la "prueba de fe" que Dios esperaba de los feligreses. Las invocaciones, la oración permanente, la participación en la misa, las devociones y las procesiones son manifestaciones de una vida espiritual necesitada de la misericordia de Dios para dar continuidad a una vida carnal regida por la humillación y el pecado. Las mujeres del pueblo se reunían con el sacerdote a rezar, a planificar las actividades sociales, organización de fiestas y caridad. Estas últimas son hoy mujeres de 70 años, que buscaban en los sacerdotes una "palabra" de aliento, una oportunidad para sustraerse de la "humillación" y del aburrimiento de la vida doméstica. La purificación religiosa involucraba también a los indígenas, vistos como seres propensos al

\footnotetext{
7 La actividad de estos misioneros estuvo destinada a controlar y a frenar el desarrollo de sincretismos y creencias heterodoxas promovidas por los miembros laicos de las cofradías. Asimismo debían reconstruir el tejido institucional asentando bases doctrinarias que permitieran contrarrestar la fuerza de los movimientos modernistas liberales y socialistas que excluían a la Iglesia Católica de la escena de decisiones políticas y económicas, y la ubicaban bajo el control del Estado y en competencia con el protestantismo (Lynch 1985).

8 Eran misioneros italianos y alemanes, respectivamente, que daban misa en latín y dictaban cursos de doctrina a los niños. La Iglesia contaba con un párroco y dos o tres sacerdotes asistentes que atendían el área de influencia de la parroquia. Vivían en la casa construida junto a la Iglesia, daban misa únicamente los domingos y recorrían la jurisdicción parroquial una vez al año para dar los sacramentos y levantar las ofrendas (Zuretti 1955 y 1972).
} 
paganismo y, por lo tanto, al pecado y a la inmoralidad.

En la década del '60, como resultado de las reformas implantadas por Concilio Vaticano II se conformaron varias organizaciones intermedias como Movimientos de Cursillos de Cristiandad, Organización de la Catequesis urbana y rural, la Acción Católica y el Partido Demócrata Cristiano, entre otros. En estas organizaciones la feligresía debería comenzar a reflexionar sobre la fe, la moral, la política y la sociedad. Las nuevas tendencias fueron implantadas por los misioneros claretianos, quienes llegaron a la región en 1968.

El nuevo estilo religioso se corresponde a la promoción de la participación de los laicos en las tareas que anteriormente estaban a cargo de los misioneros. Para ello en 1971 y 1972, la Iglesia autoriza la incorporación de laicos al trabajo de evangelización. Así nacen los primeros grupos de formación de "Animadores de la Palabra" o cursillistas, a los que asistían jóvenes y ancianos de las localidades rurales. Para los misioneros claretianos, Dios no era una fuerza misteriosa y temeraria, sino accesible y bondadosa. El énfasis en aspectos litúrgicos y doctrinales, la inaccesibilidad de los sacerdotes, de Dios y de la Biblia ceden en favor de la lectura del Evangelio y del contacto amistoso entre los sacerdotes y los feligreses.

En el contexto de la nueva espiritualidad cristiana, las tensiones y los problemas cotidianos de las personas se resolverían convirtiendo a la feligresía indígena en verdaderos cristianos, capacitados para controlar prácticas y rituales locales: ofrecer bebidas y comidas a los muertos y a la tierra, vivir en concubinato, transformar las celebraciones de los muertos en celebraciones mundanas, era para los misioneros claretianos un "exceso". Para eliminar los excesos era necesario analizar las prácticas y establecer distinciones entre la superstición y la costumbre folclórica y la auténtica religión.

El tratamiento de los excesos los llevó a eliminar la ornamentación y las imágenes de los santos y vírgenes en las iglesias. Predicaron que estas últimas no tenían ningún poder para producir milagros y transformaciones abruptas del estado de las cosas, sino que eran representaciones de vidas ejemplares. Desde el punto de vista de la identi- dad, ser católico ya no demandaba llevar una vida regida por la humillación y por el temor al castigo divino, sino una vida dedicada a la enseñanza de "la buena noticia", la resurrección de Jesús. Así, el culto a los santos fue sustituido por lecturas sobre la vida de los apóstoles. Estos seres fueron mostrados como gentes simples, quienes inspirados en "la buena noticia" toman coraje, se liberan del pecado, superan el fatalismo, la indiferencia y la anarquía imperantes en sus lugares de residencia habituales y salen a predicar el Evangelio.

El énfasis en los excesos llevó a los sacerdotes a elaborar y a implantar nuevos principios de autoridad sobre aquello que hasta ese momento la Iglesia Católica había excluido o perseguido, la visión del mundo de los koyas. Basados en la lectura de textos antropológicos intentaron restituir un sentido de origen y de respeto vinculado a los rituales y visiones andinas del mundo. En publicaciones mensuales destinadas a los animadores, a la par que distinguen los contenidos, experiencias y emociones características de los cristianos verdaderos, intentaron implantar los verdaderos significados de los rituales andinos.

\section{Las Comunidades Eclesiales de Base}

A partir de la experiencia acumulada en los cursillos de cristiandad y en consonancia con los postulados de la Segunda Conferencia Pastoral de Obispos Latinoamericanos de Puebla (1979), los Padres Claretianos celebraban la Segunda Asamblea Pastoral de 1982. En esta Asamblea los sacerdotes deciden profundizar el nuevo proyecto evangelizador a partir de promover la constitución de Comunidades Eclesiales de Base (CEBs). En las sociedades latinoamericanas las oportunidades de acceso al trabajo, a los servicios sociales, a la cultura y al poder eran desiguales. Las Comunidades Eclesiales de Base serían el medio que permitiría articular un proyecto social democratizador. Los koyas habían sido marginados del proceso social y su pobreza era producto, en parte, de la desigualdad de posibilidades de acceso a la educación y al trabajo. En las CEBs, los humahuaqueños podrían discutir sus necesidades y formular demandas a la sociedad nacional e internacional.

En la década del '80, en 24 localidades de la Prelatura de Humahuaca se implementaron proyectos destinados a generar empleo y mejoras de 
infraestructura urbana y rural. En un informe de evaluación elaborado en 1991 se destaca el impacto creciente de los proyectos de gestión comunitaria. Aumentaba el número de grupos dispuestos a organizarse, crecían y se diversificaban los montos y las esferas de inversión. Los vínculos con Misereor, Adveniat y otros organismos internacionales son muy importantes. Estas organizaciones no gubernamentales financian y asesoran a la Organización Claretiana para el Desarrollo (OCLADE) en términos de gestión. OCLADE centraliza en la ciudad de Humahuaca el manejo gerencial y administrativo de los proyectos llevados a cabo en las localidades rurales y urbanas. A través de estas organizaciones los profesionales de OCLADE se aseguran fuentes de financiamiento para su trabajo y para la capacitación de los nuevos dirigentes eclesiales.

La labor en las CEBs, el contacto con el trabajo de cientistas sociales y de un conjunto de expertos, llevó a los sacerdotes a cambiar sus perspectivas. El pueblo koya comenzó a ser descrito como producto de la colonización y de la marginación geográfica, cultural, económica y política. La dominación, la opresión y la manipulación habrían dado lugar al desarrollo de personalidades enajenadas. Los bajos niveles educativos, la aridez de sus campos, el aislamiento geográfico, las casas incómodas, sus hábitos alimentarios y costumbre de mascar coca para insensibilizarse, los convertía en personas "radicalmente pobres". Todo esto era corroborado y sostenido en las actitudes de desprecio y en la desvalorización que ellos y su cultura despertaban en los foráneos (Olmedo 1994). Para transformar esta situación era necesaria una liberación del pueblo koya. Esta se llevó a cabo en dos planos. En primer lugar, profundizando el proyecto de purificación y la incorporación de correctivos a la religiosidad koya como una forma de reescribir la conciencia "fatalista y enajenada". En segundo lugar, la nueva conciencia sería el producto de la implantación de proyectos destinados al fomento del desarrollo empresarial (Olmedo 1994).

Las CEBs comenzaron a funcionar por iniciativa de los padres y de los líderes naturales de las localidades rurales. La capacitación y la implementación de proyectos tuvo como resultado la formación de un nuevo estrato de laicos, los animadores, quienes median las relaciones entre los vecinos y los miembros de la Iglesia. Esto permitió a personas que nunca habían tenido acceso a una educación religiosa formal, obtener títulos y cargos dentro de la Iglesia. Entre 1982 y 1995, 800 personas atendieron los cursos de capacitación, 300 de las cuales obtuvieron un título de animador. En 1997 la Iglesia contaba con 250 animadores activos.

\section{La misión bautista}

En Argentina el fundador del bautismo actual fue Paul Besson, un suizo francés ordenado en la Iglesia Reformada. ${ }^{9}$ Se instala en Buenos Aires y lleva a cabo el primer bautismo en el mismo Río de la Plata, en 1883. Su principal actividad consistió en aportar argumentos jurídicos, doctrinales e históricos a las discusiones políticas sostenidas entre la élite religiosa y las ideas de la élite liberal -Roca, Wilde, Sarmiento- en favor de la escolaridad laica, cementerios seculares, matrimonio civil y supresión de actos religiosos en los actos militares (Canclini 1981).

En 1948 llegan los primeros misioneros bautistas a la ciudad de Humahuaca. Se trataba del pastor norteamericano Gerow y de su esposa. Se instalaron en un paraje cercano a la ciudad y en los años subsiguientes acogieron a las doce parejas enviadas por la Conferencia General Bautista (Wardin 1995: 333 y 334). Los misioneros bautistas conservadores enseñaron a la gente que no existe una doctrina ni una ordenación sagrada que diferencia a los más dotados del resto, sino que las personas son pecadoras y el pecado produce malestar. La fuente del pecado es el deseo incontrolado producido por influencias demoníacas. Frente a ello, los misioneros proponen la conversión de personalidades regidas por la culpa, en personas espirituales controladas por la voluntad de vivir la vida en el perdón de Cristo (Shelley 1973).

¿Cómo se produce la conversión? A través del sentimiento de pertenencia a una congregación de regenerados. El diablo obra constantemente en este mundo produciendo pecados. Frente a ello Dios

\footnotetext{
9 El primer misionero bautista que llega a Argentina fue el escocés James Thompson en 1820 como ministro enviado por la Sociedad Bíblica Británica y la Sociedad Lancasteriana. Estas pretendían introducir reformas en el sistema escolar y promover leyes que consagraran la libertad religiosa y la separación de la Iglesia y el Estado (Wardin 1995).
} 
propone el perdón y la reconciliación. Los bautistas celebran dos rituales centrales, el bautismo y la cena. El bautismo supone una decisión de creer en la muerte y en la resurrección de Jesús, y esto es asociado a la muerte del yo individual concebido en el pecado y a la resurrección de un yo social en el perdón. Finalmente, la Cena del Señor es un acto que expresa la muerte y la esperanza del retorno de Cristo. Se trata de un acto corporativo, una mesa familiar, un cuerpo participante de la muerte, de la resurrección, del retorno y de la salvación (Shelley 1973).

Rechazan la idea de mediación humana entre Dios y la feligresía a través de la conformación de una estructura de ordenación. Predicar y orar no consisten en la repetición de frases hechas por parte de un agente religioso, sino que "la palabra" es "inspirada". La palabra inspirada se manifiesta en cualquier persona y consiste en la expresión de un estrecho contacto con Dios. Por esta razón predicar la palabra es una de las actividades centrales de la vida de los bautistas (Shelley 1973). En los aspectos político-organizativos conforman congregaciones locales autónomas respecto de las superestructuras eclesiales. La acción eclesial no está basada en un cuerpo regulado por normas. Se espera que la Iglesia local con la guía de las Escrituras, establezca sus propias formas de autoridad y de administración. La membrecía organiza las actividades, hace visitas sociales, enseña e interpreta la palabra. Sin embargo, una congregación puede tener un anciano, pastor o diácono a cargo de la organización de estas actividades. La ordenación de pastores o diáconos no responde a la ocupación de un cargo, sino que es el resultado de un "llamado" divino (Shelley 1973).

Los bautistas promovieron además el principio reformista de la libertad religiosa asociada a la posibilidad de profesar una fe diferente a la dominante. El Estado puede constituirse en un poder opresor de otras ideologías o religiones. Con su mensaje, los bautistas pretenden propagar su oposición a los sistemas eclesiásticos, como el católico y las variantes sincréticas surgidas del contacto.

\section{La Iglesia Bautista Conservadora}

Recién en 1955 se crea en Humahuaca la Iglesia Bautista de la Puna y la Quebrada de Humahuaca.
La Iglesia contaba con 51 miembros. ${ }^{10}$ En 1969 la Iglesia tenía 351 miembros y se había convertido en lugar de retiro y de encuentros de la Asociación General de Iglesias Bautistas del Noroeste Argentino. La Asociación contaba con dos seminarios de formación pastoral en las ciudades de Salta y Tucumán. En 1995, veintisiete años más tarde, había 17 Iglesias bautistas en la región y el número de feligreses se mantuvo en 342.

Conforme al informe del que disponen los misioneros, los pobladores locales tenían raíces indígenas, pero la conquista había dejado sus huellas aculturadoras, dado que la lengua local no era el quechua sino el lenguaje de los "conquistadores". La influencia dominante del Virreinato del Alto Perú había dejado su marca en la sociedad local, vista como conservadora, tradicional y lenta frente al cambio. Finalmente, en el informe se destaca que pese al voto universal, las masas marginales del Noroeste Argentino no fueron incorporadas al bienestar económico (Misión Bautista Conservadora s/f Ms).

Consideran que la mayor parte de los miembros de la Iglesia Bautista local la constituye este elemento marginal de la sociedad, visto como definitivamente propenso al cambio, dada su búsqueda de identidad. Desde el punto de vista de la misión, la masa marginal brinda abundantes oportunidades de identificación y de asistencia en su búsqueda de sentido de la vida y de la muerte. Los misioneros bautistas actuaron exactamente al revés que los misioneros católicos. No se interesaban por la élite, sino que su trabajo consistía en salir de los pueblos y viajar por los cerros para llegar a los indígenas. Entre 1957 y 1984 el misionero Carlos Gerow y su esposa, los Ferguson y finalmente el misionero Johns mostraron a la gente que la Iglesia Católica tergiversaba la Palabra de Dios y que, por lo tanto, ellos vivían en el engaño y en la ignorancia religiosa. El engaño y la ignorancia explicaban la ausencia de fortaleza moral para enfrentar los pe-

10 Por aquel entonces el bautismo contaba con un total de 365 miembros en las tres provincias que forman parte de la Asociación Bautista del Noroeste Argentino. Los datos recolectados por la propia institución muestran que, desde 1969 hasta la actualidad, la Asociación ha sumado miembros paulatinamente. En 1969 contaban con 1.489, en 1979 con 2.401 y en 1995 con 4.950. Algo completamente distinto ocurre en Quebrada y Puna, donde el número de miembros se mantuvo completamente estable en los últimos 27 años. 
cados de la carne y sus consecuencias en la vida cotidiana: la violencia doméstica, la flojera frente al trabajo, la búsqueda de ayudas externas en las redes políticas estatales.

Para terminar con el malestar que estas experiencias ocasionaban, los misioneros proponían llevar adelante un proceso de purificación religiosa que permitiera disciplinar los cuerpos y la imaginación indígena, ahora vista como residuos de la manipulación de la Iglesia Católica. Este proceso suponía una ruptura con el sincretismo religioso, visto como errado. Repartieron Biblias para que las personas pudieran conectarse cotidianamente con la Palabra de Dios y alentaron a la población a reunirse en casas de familia para leer y para conversar sobre la Biblia. A medida que la membrecía aumentaba, se fundaron las Iglesias. Los misioneros esperaban que los feligreses se ocuparan por sí mismos de las actividades litúrgicas y de la administración de la congregación.

El énfasis de los misioneros en la organización autónoma y en la libre interpretación de la Biblia llevaron a algunos miembros de la Iglesia Bautista de Humahuaca a emprender viajes destinados a predicar, a convertir, a orar y a defender públicamente un nuevo estilo de vida basado en las enseñanzas bíblicas. Este nuevo estilo se caracterizaba por la independencia y la oposición frente al status-quo: las superestructuras institucionalizadas del catolicismo romano que basaban su autoridad en el ocultamiento de la Biblia, en la ausencia de controles externos en la administración de los bienes eclesiales y en el ocultamiento de la vida íntima del clero.

Carlos Gerow escribía en 1955 que en los primeros seis meses habían mantenido 22 encuentros y que, en ellos, 50 personas habían hecho votos de fe al Señor. Los líderes de los caseríos ubicados en los cerros les manifestaban que toda la comunidad había decidido convertirse al Evangelio y los pobladores hacían filas para recibir la Palabra de Dios personalmente. Quienes sabían leer transmitían a quienes no sabían leer los nuevos conocimientos escritos en la Biblia (Gerow $1997 \mathrm{Ms}$ ). ${ }^{11}$ Las cartas de los misioneros abundan en relatos

11 Excerpt $\mathrm{N}^{\circ} 1$. Los "Excerpts" son párrafos escogidos de las cartas que el matrimonio formado por el misionero Gerow y su esposa enviaron a sus familiares y a la misión durante los años en que ellos trabajaron en el Noroeste sobre personas que dejaban de beber, de robar y de tomar drogas ${ }^{12}$ para convertirse en trabajadores responsables, atractivos para sus patrones.

Las sucesivas parejas de misioneros proyectaron imágenes de armonía familiar y de fortaleza de los lazos familiares, frente a lo cual los pobladores se sintieron atraídos. Mientras los misioneros bautistas tenían parejas e hijos, cooperaban con sus esposas tanto dentro como fuera del hogar, invitaban a los pobladores a sus casas y los visitaban en las suyas, los sacerdotes y los funcionarios vivían una vida familiar y sexual rodeada de "misterio" y de contradicciones entre el discurso moral de la unión familiar y la práctica cotidiana de las aventuras amorosas clandestinas.

Cuando los pastores norteamericanos abandonaron la Iglesia de Humahuaca, se inició una crisis de autoridad en la congregación. La conducción de la Iglesia quedó a cargo de los feligreses, quienes dan continuidad a su administración, a los rituales, y se alegran de recibir la visita de misioneros para estar al tanto de las novedades teológicas. Pero, dado el conflicto interno decidieron no realizar campañas para atraer a nuevos feligreses. Mientras algunos misioneros consideran que su obra produjo conversiones y transformaciones de la vida de las personas, otros consideraban que la gente no es "verdaderamente cristiana" y que la conversión es un camino de largo plazo. El énfasis de los misioneros en contenidos muy asociados a un simbolismo abstracto, característico de la formación teológica universitaria, en detrimento de los aspectos rituales y de la experiencia llevaron a que un grupo de feligreses se abriera y se conformara una nueva Iglesia Bautista en la región: la Iglesia Bautista Renovada.

\section{Juventud y "las costumbres de estilo"}

La sociedad de Jujuy es una sociedad vieja. Los jóvenes emigran de la provincia para buscar mejores posibilidades de trabajo y para estudiar en la Universidad. Las carreras profesionales más

Argentino. La selección de los párrafos fue realizada por ellos mismos con el objetivo de que sus hijos, nietos y otros lectores interesados en la historia de la misión pudieran leerlos. Una copia de los "Excerpts" me fue enviada por Charles Gerow en julio de 1997.

12 En este caso, se refieren a que la gente masca hojas de coca para estar animada y no sentir hambre. 
populares suponían el acceso a la educación superior para acceder a puestos mejor remunerados en el sector agrícola, en la industria y en los servicios. Mientras los varones buscaban empleo en la agroindustria, construcción, minería, transporte y servicios de salud, las mujeres solían hacerlo en los servicios educativos y sanitarios y en el comercio. Asimismo, desde la década del '80 en adelante, las sucesivas administraciones provinciales generaron expectativas en relación con la implementación de la legislación que regula la tenencia de la tierra; el otorgamiento de créditos blandos con vistas al desarrollo de la pequeña producción pastoril y agrícola; el fomento de actividades comerciales a partir de declarar a la región "zona franca" o libre de impuestos, y del crédito para el desarrollo de pequeñas empresas de servicios turísticos y artesanales. Las expectativas de carrera profesional y de éxito económico vinculadas a este modelo de desarrollo llevaron a los adultos a invertir tiempo y esfuerzo en la educación de sus hijos. ${ }^{13}$

Sin embargo, desde comienzos de la década del '90, los jóvenes de la región comenzaron a ver que sus posibilidades de conseguir un puesto de trabajo fuera de la región, así como de lograr éxitos económicos, disminuían respecto a las de sus progenitores. Las políticas de reconversión tecnológica y de ajuste fiscal implicaron que la oferta de puestos de trabajo en el sector público y privado decreciera. Por otra parte, la hiperinflación y posteriormente la llegada masiva de productos de otras regiones, llevaron a la depreciación de la producción local (agricultura, ganadería, tejeduría, etc.).

Pese a ello, la mayor fluidez del intercambio fronterizo, el turismo y los medios masivos han incrementado la presión sobre los jóvenes. El éxito profesional, la disponibilidad de dinero, el consumo de ciertos bienes, ropa y calzado deportivo, música, videos, computación, alcohol, sexo y equipos electrónicos son cuestiones que obsesionan a los jóvenes de Humahuaca. Los jóvenes no buscan salidas a estas obsesiones, simplemente porque todavía no las han planteado en términos de

13 Aun cuando la educación pública es gratuita, estudiar supone comprar uniformes, útiles escolares y dedicar tiempo a las tareas escolares. Asimismo, los jóvenes que inician el ciclo de educación secundaria ocasionan gastos en lugar de ingresos, y los padres estaban dispuestos a apoyarlos para garantizarles un "porvenir". problemas vitales. Los jovencitos que entrevisté y observé han vivido situaciones de violencia doméstica, angustias y depresiones de sus padres por falta de dinero y de trabajo, desprecio de parte de quienes se ven a sí mismos como parte de la cultura ilustrada y blanca, y desean adquirir los bienes que la sociedad de consumo les ofrece. Sin embargo, no se muestran interesados por participar de las instituciones de las que disponen para transformar la sociedad en la que viven. Mantienen distancia de las reuniones religiosas en las localidades o cuando se acercan están distraídos y juegan entre sí. En cuanto a las actividades de capacitación y de lectura de la Biblia que organizan las Iglesias, se limitan a acompañar a sus padres y a veces colaboran en la cocina, en servir las comidas o con la limpieza, pero durante las reuniones y las discusiones permanecen en silencio. La Iglesia representa para ellos la autoridad, responsabilidades, costumbres hogareñas y coacción. Ellos relacionan a la Iglesia con la condición de personas maduras que sostienen relaciones con los funcionarios del Estado, los partidos, emprenden trabajos en las localidades o en los barrios, soportan presiones de todo tipo, se enferman y prefieren mantenerse al margen de ello.

Tanto los jóvenes católicos como bautistas recuerdan que aprendieron de sus mayores cómo orar y cómo adorar a la Pachamama, a Dios, a Jesús, a la Virgen y a los Santos, y desprecian la falta de "sinceridad" y de "entrega". Sin embargo, los jóvenes consideran que los adultos realizan los rituales y celebraciones religiosas públicas de forma mecánica, para cumplir con las convenciones, o instrumental, para obtener algún beneficio. En este sentido, las prácticas y los discursos religiosos o ideológicos eran vistos como parte del simulacro que rodea la vida adulta.

Cuando comentaban la falta de oportunidades de trabajo y las escasas posibilidades de acabar exitosamente una carrera universitaria, no se les ocurría qué cambiaría de esta situación si ellos participaran de los cursillos, de las Celebraciones de Palabra o de las reuniones religiosas en la congregación. Si los sacerdotes y los ancianos presionan a los padres, los jóvenes asisten a cursos y reuniones para cumplir con las demandas de los progenitores, pero paulatinamente abandonan y se dedican a estudiar, a trabajar, a vagar y a reunirse con chicos y chicas de su edad en barras, escuchan música o miran televisión. 
Sin embargo, la mayor parte de los jóvenes coincidían con los adultos en que las procesiones, las celebraciones y las reuniones religiosas, tanto en el hogar como en las localidades o en la ciudad, podían ser vistas como parte de la diversión y como acontecimientos en los cuales se ponen de manifiesto las tensiones existentes entre los jóvenes y los adultos. Así las demostraciones de devoción religiosa de los adultos eran objeto de broma:

“...antes era diferente (cuando era un niño). Ahora (18 años) si un adulto adora bien, te ríes. En una oportunidad, una abuela que va con el cuarto $^{14}$ saltando así bien despacito y nosotros nos reíamos... y los abuelos reniegan. No les gusta. En el tema de rezar lo mismo..." (Pablo, Humahuaca, 1995)

Los humahuaqueños asocian los rituales religiosos a las "costumbres de estilo" que aprendieron de sus ancestros indígenas. "El estilo" particular de los humahuaqueños, refiere al avance del ciclo agrícola y la celebración de las fuerzas sobrenaturales que habitan en el paisaje: Pacha identificada con las profundidades de los cerros y simbólicamente femenina, y los cerros mismos identificados con las alturas y con el contacto con el sol, y simbólicamente masculinos. Estas fuerzas sobrenaturales favorecen la fertilidad de los campos y con ello la continuidad de la vida en las localidades. Durante los rituales religiosos la gente se "enfiesta", es decir, celebra a las entidades sobrenaturales y a la fertilidad. ${ }^{15}$ Enfiestarse y celebrar supone el consumo abundante de bebidas, comidas y coca además de la realización de bailes y de ofrendas a las fuerzas sobrenaturales.

En las celebraciones religiosas tanto los varones como las mujeres se muestran abiertamente activos frente a posibles conquistas sexuales. En estados de ebriedad la gente se "anima": los varones se "atreven" a acercarse a una mujer y las mujeres repiten que ellas tuvieron sus primeras experiencias sexuales debido a que estaban "enfiestadas", todo sucedió porque, "las chinitas

14 La "cuarteada" consiste en una ofrenda ritual de corderos a las entidades sobrenaturales locales y universales o cristianas y no cristianas (Lozano 2001).

15 Para una descripción detallada de la relación entre rituales religiosos y género en Ronque ver Lozano (2001). Para una descripción e interpretación detallada entre ebriedad, rituales religiosos y memoria en los Andes ver Saignes (1993). estaban machadas" (ebrias) y los "changos se aprovechan" cuando las jóvenes pierden el control. "Celebrar", "animarse", "enfiestarse", "macharse" son formas de simbolizar la atracción sexual, la fertilidad y la vida en términos religiosos y del género. Incluso el flirtear no excluye la rivalidad, el rechazo y la agresividad entre los amantes como forma de llamar la atención. La atracción y la rivalidad sexual pueden estabilizarse y transformarse en una relación de "respeto" que privilegia la mutualidad y las jerarquías del parentesco, conocida como "servinacui" o "matrimonio a prueba". Las relaciones de mutualidad suponen la división sexual del trabajo: la provisión de recursos al hogar y a la comunidad es simbólicamente masculina, mientras que las actividades vinculadas a la administración y al procesamiento de los recursos del hogar y de la comunidad son simbólicamente femeninas. Sin embargo, tanto las mujeres como los varones salen a trabajar fuera de los hogares y proveen de recursos. Esto supone una readaptación continua de las pautas que regulan las relaciones de mutualidad en el contexto de los hogares y de las localidades. Estas prácticas y convenciones sociales son conocidas como parte de las "costumbres" o "el estilo".

Las celebraciones religiosas tienen entonces significados culturales implícitos. En el contexto de los rituales religiosos las diferencias sexuales adquieren significados culturales en términos del género, de las relaciones de parentesco y de los vínculos con las entidades sobrenaturales que favorecen la producción y la reproducción de la vida en la tierra.

\section{Los jóvenes y las Comunidades de Base}

Desde el punto de vista de los sacerdotes, los problemas que enfrenta la juventud están relacionados a dos cuestiones. Por un lado, a las escasas oportunidades de trabajo y de estudio existentes en la región, que obligan a los jóvenes a emigrar. Por el otro lado, a la incitación permanente al consumo de bebidas alcohólicas y al sexo que puede desembocar en una sexualidad irresponsable, en la violencia y en adicciones.

En las revistas y en los cursos de capacitación dictados en la ciudad de Humahuaca a los animadores, las enseñanzas de los sacerdotes en relación con el comportamiento de los jóvenes son contradictorias. Por un lado, los misioneros invi- 
tan a los jóvenes a recrear una comunidad y una cultura indígena basada en compartir condiciones de vida y conocimientos religiosos y culturales en lugar de participar de una cultura urbana, materialista y violenta. Por el otro, esperan que los jóvenes separen "lo verdaderamente religioso (de los rituales indígenas) de las fantasías y los excesos paganos".

Para contrarrestar a las tentaciones piden a los jóvenes que escuchen "la voz de Dios en el interior de cada uno", en lugar de escuchar las invitaciones a la celebración de los vecinos. Ni en las localidades del campo ni en las ciudades, los misioneros prohíben la asistencia a fiestas y el consumo de bebidas en las celebraciones religiosas. En las CEBs y en los cursos de capacitación se promueve el juicio crítico y el autocontrol del individuo a partir de la toma de conciencia en grupo, la lucha y el compromiso para transformar las costumbres no apropiadas de la comunidad en su conjunto. Pero no se toman medidas para conseguirlo.

Frente a la falta de autocontrol concreta, los sacerdotes sugieren, a través de una particular mezcla de reto y de humor, desarrollar la conciencia y la responsabilidad individual. Por ejemplo, en los almuerzos realizados durante los cursos de capacitación y en las celebraciones a las que asistí, se sirve alcohol. Cuando los animadores "se dejan tentar", es decir, beben y se embriagan, los sacerdotes, los docentes y los animadores retan a las personas ebrias y les recuerdan que deben controlarse. Inmediatamente después del reto, relajan la tensión contando chistes sobre la "flojera" de los animadores.

Patricia, una animadora de 19 años comentaba con espanto que los bautistas prohíben a los miembros de las congregaciones beber alcohol y asistir a fiestas. Sin embargo, ella reconoce que la prohibición de tomar alcohol produce efectos en las percepciones de las personas sobre los otros y sobre sí mismas: “...son como los santos... no hacen nada". Cuando le pregunté si la prohibición no le parecía una medida adecuada para acabar con las adicciones y los excesos, me contestó que personalmente no sabía. Pero destacó que el propio Obispo les decía que tenían que respetar a los bautistas y aprender de ellos. Ellos demostraban que se podía renunciar al alcohol, superar adicciones y que ello contribuía a consolidar re- laciones. Los bautistas no vivían en el descontrol, sino que adoraban y celebraban a Dios sin necesidad de embriagarse. A diferencia de ellos, "los que se dicen católicos" no se controlan y dan malos ejemplos a los jóvenes.

Una de las cuestiones que genera confusiones en los jóvenes es la falta de apoyo que los animadores reciben de la Iglesia una vez que terminan los cursos de capacitación destinados a la formación de líderes religiosos:

“...cuando te estás preparando estás entusiasmado, pero cuando terminas el curso, ya no estás enganchado. Los padres vienen poco y no hacen apoyo y seguimiento de los animadores" (Juan Carlos, Humahuaca, 1993).

Doce sacerdotes están a cargo de la atención de las necesidades religiosas de los siete departamentos que conforman la Prelatura. Por lo tanto, la responsabilidad de motivar la presencia de los vecinos en las Celebraciones de la Palabra recae exclusivamente en los animadores. Los mayores se resignan fácilmente a las ausencias de los vecinos y siguen, participan u organizan celebraciones religiosas acorde a su disponibilidad de tiempo y a sus obligaciones. En cambio, los jóvenes se resienten frente al desinterés que caracteriza a las relaciones entre los vecinos y a las celebraciones religiosas en los hogares o en las mismas iglesias.

El noviazgo, las relaciones de pareja y el matrimonio son los temas que mayores controversias desencadenan entre los jóvenes y los misioneros. La Iglesia recuerda que el matrimonio y la formación de una familia es el resultado de un enamoramiento profundo. El enamoramiento predispone a las personas a grandes renunciamientos individuales para complacer a la persona amada. Estos renunciamientos encuentran su fundamento en el amor existente entre los miembros de la pareja. La base del éxito de una unión entre dos enamorados es el desarrollo de la conciencia, del diálogo y de la reflexión. Conforme a los textos publicados en cartillas y revistas y las recomendaciones de los sacerdotes vertidas en cursos, el desarrollo de la conciencia, del diálogo y de la reflexión entre los futuros contrayentes requiere de tiempo, de paciencia y de esfuerzo: “... no hay carrera más importante que el matrimonio... si le dedicamos años a carreras como la medicina, la abogacía, por qué no dedicar tiempo a la carrera 
matrimonial?...". En revistas y publicaciones especialmente destinadas a los jóvenes, los misioneros hacen comparaciones y mencionan pautas abstractas que permitirían lograr una convivencia madura: en contraposición a las uniones circunstanciales (basadas en impulsos), patriarcales (basadas en la obligación), el amor conyugal es una construcción basada en la responsabilidad individual:

“... para la gente es difícil entender la propuesta de los sacerdotes. Pero yo no estoy de acuerdo con los sacerdotes tampoco. Dejan que la gente se case y bautice a sus hijos (aún) sin haber hecho los cursos. El padre estuvo a punto de hacerlo, si yo no lo freno..." (Juan Carlos, Humahuaca, 1993).

Los sacerdotes saben que los humahuaqueños no disponen de tiempo y que tienen dificultades para entender los mensajes emitidos por los misioneros en los cursos, pero que celebran con gusto rituales religiosos. Por estas razones, si bien promueven la participación en cursos, están dispuestos a bendecir uniones aun cuando saben que los contrayentes no conocen o no entienden el significado que la Iglesia otorga a las uniones matrimoniales. Estas disparidades entre el discurso y la práctica cotidiana de los sacerdotes constituyen unos de los motivos por los cuales los jóvenes suelen desacreditar a la prédica de los sacerdotes y a la Iglesia Católica en su conjunto.

Los jovencitos que circulan por las CEBs no están preocupados por el matrimonio y consideran normal sostener relaciones ocasionales y "probar". ${ }^{16}$ Especialmente quienes tienen la oportunidad de estudiar (varones y mujeres) coinciden en que es propicio evitar compromisos hasta finalizar los estudios y consolidar sus posiciones laborales. En particular las jóvenes se mostraron inte-

16 Los sacerdotes difunden el modelo del "noviazgo" una vez que los enamorados declaran su interés en iniciar un contacto regular con la finalidad de contraer matrimonio. Así cesa la etapa de la búsqueda de candidatos y se inicia el noviazgo durante el cual la pareja se prepara para el matrimonio: construye la vivienda, compra los muebles y utensilios necesarios para equiparla, pero no tiene relaciones sexuales. A diferencia de ello, en los Andes el "matrimonio a prueba" supone que la pareja basa su contacto no en el interés de casarse, sino en la atracción sexual experimentada por ambos miembros de la pareja, que puede derivar en la estabilización de la relación. resadas en obtener información sobre el uso de dispositivos anticonceptivos. Este es un tema difícil de tratar, tanto dentro de la iglesia como en los hogares y en la situación de entrevista. Las jóvenes sentían pudor de hablar abiertamente sobre el tema. Asimismo, consideraban imposible obtener información confiable y sólo accedían a ella a través de relatos de amigos o de la publicidad televisiva y no veían posible acceder regularmente al uso porque no disponían de dinero. Mientras las jóvenes enfatizaban que el amor y en el noviazgo era la causa de embarazos que en la mayor parte de los casos no fueron buscados, los varones se mostraban tensos o completamente desinteresados por informarse o hablar sobre educación sexual. La consecuencia habitual de los embarazos juveniles era el abandono de la escuela secundaria por parte de la joven para hacerse cargo de los cuidados del bebé, mientras que el varón continuaba en la escuela.

Algunos jóvenes entrevistados coincidieron en que para proveer el dinero necesario para la crianza de los hijos salieron a trabajar, aun cuando no querían convivir con la madre. Se cuestionaron a sí mismos su escasa responsabilidad frente a su propia sexualidad y frente a sus estudios. Reconocen que perdieron el tiempo cuando fracasan en sus intentos por continuar estudiando en la universidad, o cuando tienen que aceptar trabajos mal remunerados y quieren formar una nueva pareja pero no tienen ni la educación ni los recursos para hacerlo.

“...cuando sos chico vas a la escuela para cumplir y piensas que tu papá va a proveer para siempre. Las chicas estudian, pero los varones no, flojeamos. En Jujuy no aguanté ni un mes trabajando de empleado, bajo patrón. Yo me quiero capacitar, si te quedas ahí postergado, nunca vas a hacer nada más que trabajar como un "negro". Si no trabajas estás colgado y si estás colgado no te quiere nadie..." (Juan Carlos, Humahuaca 1993).

Los sacerdotes promueven que los jóvenes contraigan matrimonio una vez que hayan acabado con sus estudios y hayan obtenido un empleo, sin embargo, la prohibición del uso de anticonceptivos y la ambivalencia de los sacerdotes frente a las prácticas sexuales prematrimoniales, resultan problemáticas para los jóvenes. Por un lado, los sacerdotes esperan que los jóvenes eviten las relaciones sexuales antes del matrimonio pero, por 
otra parte, admiten celebrar matrimonios entre personas que llevan varios años de convivencia y que asisten a los cursos y a la iglesia con sus hijos. Para los jóvenes resulta complicado entender cómo es posible que quienes han abandonado la escuela o la universidad, han tenido relaciones e hijos antes de contraer matrimonio se conviertan en líderes religiosos. La ambivalencia de los sacerdotes frente a las normas que regulan el comportamiento de los católicos generan críticas y desconfianza entre los jóvenes.

Otro aspecto conflictivo es la conformación de un liderazgo basado en el voluntariado juvenil. Fausto, un animador de 19 años, había asistido a los cursos de catequesis y había tomado la Primera Comunión sin convencimiento, "por cumplir" con las demandas de sus progenitores. Un vecino le propuso asistir a los cursillos con él, y a pesar de que ambos pensaban que la religión eran macanas (fantasías), decidieron tomar los cursos. Una vez que éstos finalizaron, Fausto comenzó a trabajar en actividades de capacitación y de organización con los sacerdotes. Con el tiempo y asistiendo regularmente a los cursos de capacitación esperaba transformarse en promotor social remunerado de la ONG. Le interesaba el video y el cine, pero soportaba el "trabajo honorario en sanidad animal en las comunidades", con la esperanza de que surgiera una oportunidad "interesante".

Convertirse en empleado público de baja categoría o ser un productor andino con bajísimos rendimientos es algo que ninguno de los animadores jóvenes considera. En efecto, los jóvenes quieren formarse para poder modernizar el manejo de sus establecimientos agropecuarios, obtener mejores rendimientos o para obtener puestos de trabajo mejor remunerados en los servicios. Los sacerdotes conocen esta realidad y la utilizan con consecuencias problemáticas para todos. Por un lado, los sacerdotes se quejan del escaso interés que muestran los jóvenes por trabajar para la comunidad, al mismo tiempo reclutan jóvenes que no necesariamente están interesados en realizar actividades no remuneradas, sino que están buscando oportunidades de empleo.

Construir relaciones que garanticen el bienestar material de una familia es símbolo de capacidad. Esto no parece ser un desafío fácil para los jóvenes que viven en los Andes y una de las salidas posibles es descubrir su vocación de transformar- se en sacerdotes. Pablo piensa que si fracasa como programador social o agricultor podría convertirse en sacerdote:

“...la carrera religiosa sería lo último, si no puedo trabajar en la agricultura, no puedo estudiar y no me va bien como promotor...bueno tienes que ser cura. En vez de tener una familia pobre, con problemas, prefiero estudiar para cura y volver acá para poder ayudar..." (Pablo, Humahuaca, 1993).

Cuando le pregunté si no deseaba casarse y tener hijos, me contestó que no quería "llenarse de hijos y ser pobre".

Las jóvenes aspiran a encontrar un varón hogareño y trabajador, que controle la ingesta de alcohol y que no las abandone o salga con otras mujeres. Al igual que los varones ellas esperan terminar sus estudios para mejorar sus posibilidades de encontrar empleos agradables en lugar de vivir "aisladas en las localidades" y tener permanentes dificultades para relacionarse. Ana, una joven agricultora de 19 años, que recientemente se había integrado a los cursos de capacitación, contaba que sus vecinas la habían impulsado a capacitarse "... (hay que hacer) mucho sacrificio ... para seguir adelante, para saber pensar, hablar bien y salir de casa...". Ana vivía con un joven desde hacía unos meses, no quería tener hijos hasta que tanto ella como su compañero no generaran ingresos suficientes. Cuando le pregunté si ella pensaba que asistir a los cursos le iba a ayudar, contestó lo siguiente:

“... antes estuve con mamá y con papá. Ellos hacían todo. Trabajaban y a nosotros no nos faltaba nada (a ella y sus siete hermanos)... un mundo aparte. Pero ahora pienso que si no trabajo, no comemos, ahora somos los dos solos ... y quiero trabajar..”" (Ana, Humahuaca, 1993).

A los jóvenes no les agrada hablar de sus propias interacciones violentas. Refieren a la violencia en Humahuaca, como si fuera ajena a sus interacciones sociales. Son "ellos", la población que vive en las localidades rurales, quienes tienen problemas de descontrol. Cuando hablan de violencia tienden a tratarla como si se fuera algo que han visto hacer a otros, vecinos, pero sólo ocasionalmente refieren a sus propias experiencias. Suelen confesar, con vergüenza, que aspiran 
a controlarse lo suficiente para evitar conflictos familiares y sufrimientos a sus esposas e hijos. En la Iglesia Católica estos conflictos centrales de la vida de los trabajadores asalariados y de las familias donde existen desocupados ${ }^{17}$ suelen ser tomados como parte del folklore o de las costumbres "paganas", y son ridiculizados o transformados en objeto de prolongados monólogos moralistas.

Los jóvenes que participan en las comunidades se integran por continuidad con una historia de conversión al catolicismo familiar y porque los líderes laicos impulsan a aquellos que “... vienen un tiempito y no dejan, ahí hay que ayudarle y si ves que es constante, que el día de mañana puede estar en la iglesia...". Se trata de viejos militantes de la Iglesia y de diversos partidos políticos que sostienen lazos con todas las instituciones y que consideran que los jóvenes pueden ayudarlos con los trabajos que ellos no pueden hacer, porque no tienen tiempo o porque no entienden cómo se hace cuando han asistido unos pocos años a la escuela. Ellos fomentan en los jóvenes aspiraciones de ascenso social, los impulsan a capacitarse permanentemente para estar actualizados y los incitan a beber. La participación en los cursos de capacitación que ofrece la Iglesia es una forma de acceder al manejo de técnicas de programación y de control social de las comunidades también.

Es por ello que los jóvenes que persisten en las actividades que la Iglesia propone, son aquellos que han tenido posibilidades de estudiar porque sus familias tienen ingresos estables y pueden aspirar a encontrar puestos en el Estado y a ascender socialmente. A pesar de que son buscados por la institución, ellos tienen escasas posibilidades de transformar aspectos de la vida comunitaria local. En una oportunidad, un activo programador me pidió que "transfiriera instrumentos de investigación de la realidad" a un grupo de jóvenes que comenzaban a tomar clases de comunicación social (video) para que ellos investigaran "las necesidades sentidas de la gente" y las contaran a través de las imágenes. Cuando le sugerí trabajar

17 El problema de la adicción al alcohol suele emerger con relación al trabajo asalariado, a la disponibilidad de dinero y a la ingesta de bebidas alcohólicas con los colegas, y con relación a la disponibilidad de tiempo de los varones desocupados reunidos en el bar. con algún artista local para que ellos buscaran formas expresivas de aquello que querían mostrar me contestó que "...la cultura es para los de la ciudad, ellos tienen que mostrar la pobreza...".

Los jóvenes aspiran a formar parte del mundo de los profesionales, no quieren ser identificados con un mundo y una identidad campesina-indígena constituida por de creencias siempre iguales a sí mismas. Ellos quieren verse a sí mismos y ser vistos como personas educadas y capaces de conectarse y producir en el contexto de las instituciones religiosas y seculares.

\section{Los jóvenes bautistas}

Los misioneros bautistas proponen que para recibir "bendiciones" hay que alejarse del pecado y convertirse. El motor de la acción social no es la transformación de las condiciones materiales de vida y la pobreza, sino en la capacidad de las personas de regenerarse e influir sobre la regeneración del grupo familiar y de los vecinos. $\mathrm{La}$ solidez de la familia cristiana no reside en la adopción de los sacramentos, sino que ésta se encuentra en el abandono del mundo, en la conversión y en el cumplimiento de los mandamientos. Cuando las personas aceptan a Jesucristo nacen de nuevo. El bautismo adulto supone que el bautizado aceptó a Dios conscientemente como el orientador de sus actos y, por lo tanto, estará dispuesto a destinar sus fuerzas vitales a resistir tentaciones.

Para evitar conflictos familiares los misioneros proponen como primera medida formar pareja entre los hermanos de la congregación. Tanto las jóvenes como los jóvenes ven en la "hermandad" la garantía de que los posibles candidatos orienten sus vidas conforme a los principios bíblicos sin dejarse distraer. Así los jóvenes bautistas evitan relaciones con personas "vanidosas" interesadas por las cosas del mundo en lugar de interesarse por la disciplina, el orden y el estudio. ¿Cómo descubrir si la atracción mutua experimentada entre dos hermanos es síntoma de amor? El noviazgo es una etapa de prueba. Si durante el noviazgo los hermanos establecen una relación de mutualidad, entonces el matrimonio es la consecuencia natural del noviazgo. La complementariedad supone división del trabajo en el hogar, los varones se ocupan de proveer al hogar y de predicar en la comunidad y las mujeres se ocupan del orden doméstico, de la crianza de los chicos y de 
apoyar las actividades espirituales e intelectuales de sus esposos.

A diferencia de los católicos, los bautistas no consideran que la castidad prevenga los celos, el incesto y la separación, sino que la conversión, la hermandad y el cumplimiento de los mandamientos producen prosperidad y eternidad. La promesa de prosperidad y de eternidad es el pegamento moral que sostiene a la pareja unida hasta que deciden tener hijos. ¿Cómo afectó la conversión el "matrimonio a prueba" y las relaciones de parentesco?

La primera generación de conversos llegó del campo a la ciudad de Humahuaca o a los centros mineros en la década del ' 50 . La vida urbana y la vida industrial ya no se regían por el ciclo agrícola y la celebración de los rituales que marcan su avance. La ruptura de la secuencia laboral vinculada a la siembra y a la cosecha, tuvo consecuencias sobre los comportamientos. El trabajo asalariado y la expansión de los derechos sociales garantizaron un flujo regular de dinero. La disponibilidad de dinero permitía a los varones comprar coca, comida y beber con los compañeros de trabajo, cuestión que ocasionaba problemas con la oficina de personal y con la cónyuge, encargada de administrar los recursos domésticos. Estas mujeres hablan abiertamente en la Congregación del problema de la "dominación" y de las agresiones cuando quieren simbolizar los conflictos derivados del manejo de los recursos domésticos. A través de la conversión, los hermanos y las hermanas bautistas se "entregaron" a Dios y "resistieron" a las prácticas religiosas y culturales dominantes. Este constituye el fundamento del "cambio de estilo de vida". Frente a la asociación existente entre celebración religiosa, bebida y fertilidad, los conversos suprimen las fiestas, vistas ahora como una celebración superflua destinada a ocasionar desgracias familiares. El resultado de ello fue la continuidad en sus puestos de trabajo, el ahorro de dinero y la disminución de la violencia doméstica.

Los jóvenes bautistas se enorgullecen de sus padres, porque estos pudieron superar estos conflictos a través de la conversión. Los jóvenes repiten: “... nosotros no conocemos esos problemas. Es diferente porque mis padres son conversos, nosotros vivimos tranquilos...".
Un aspecto central de la conversión es que los humahuaqueños no se convirtieron en forma individual, sino que el grupo familiar o un grupo de familias vecinas decidían hacerlo en forma conjunta. Comenzaron reuniéndose en las casas de los conversos y en la década del ' 70 construyeron la Iglesia de Humahuaca, a la cual asisten regularmente 40 personas. Se trata de un grupo pequeño y todos se conocen. Desde la perspectiva de los misioneros, la conversión era el resultado de una decisión individual, pero los humahuaqueños lo veían como el resultado de la evaluación de cada miembro del hogar, si todos deciden convertirse "será porque Dios así lo quiso, si no no será". Estas diferencias de visión constituían la razón por la cual los misioneros pensaban que los lugareños entendían algo completamente diferente a aquello que ellos predicaban. La gente aceptaba que cada miembro se convirtiera y bautizara en forma individual en el contexto de la congregación, pero posteriormente dentro de la congregación misma se movían y tomaban decisiones conforme al interés que orientaba al grupo familiar. Una joven comentaba lo siguiente:

“...fui la primera en asistir a las reuniones. Me escapaba de casa y me iba para asistir a las reuniones. Los misioneros hablaban diferente, conocían la Biblia y cumplían los mandamientos. Las reuniones eran agradables, todos se conocían $y$ trataban de integrarte. En casa al principio rechazaron pero se fueron entusiasmando..." (Eleonor, Humahuaca, 1995)

La particular forma de insertar el mensaje cristiano en el contexto de las relaciones familiares es la razón por la cual los misioneros consideran que la población local no es "auténticamente" cristiana. Pese a las muestras de fe explícitas en las conversiones, en la conformación de congregaciones, en el control del consumo de bebidas alcohólicas, en la construcción de iglesias, tanto los misioneros como los feligreses repiten que ellos no son auténticos "cristianos". Esto es adjudicado a la falta de conocimientos teológicos y a que su interpretación de los textos religiosos no es canónica.

Los feligreses enfatizan el valor de los aspectos rituales y de la palabra, pero no lo toman en serio, no comprenden el contenido, o entienden otra cosa. La prueba está en que no respetan los horarios convenidos, sino que las reuniones religiosas 
suelen comenzar cuando la gente llega y terminan cuando deciden retirarse. Los feligreses no aprenden una parte de la Biblia y la repiten o explican al resto, sino que hacen oraciones y letanías. Finalmente, continúan criando a sus hijos conforme a sus conocimientos culturales locales, en lugar de regirse por la Biblia. Incitan a sus hijos adolescentes a asistir a bailes y a tener relaciones sexuales prematrimoniales, no esperan que establezcan un noviazgo, no los obligan a casarse y generalmente los hijos vuelven a la congregación cuando ya tienen una familia y sienten que "fallan". ${ }^{18}$ ¿Entonces para qué iba la gente a la congregación? ¿Qué buscaban ellos en el bautismo?

Las "fallas" o las "caídas" constantes eran vistas como el resultado del "caciquismo" o la "dominación" masculina local. Los misioneros consideran que la figura del padre como jefe del hogar y como autoridad moral es central, dado que impide a los miembros de la familia relacionarse entre sí de forma autónoma, "hacen todo en familia". Los varones eran inducidos a entrar en la Iglesia por presión de sus hijos, esposas y vecinos, pero éstos no lo hacían solos, sino en compañía de sus esposas y de sus hijos. Esto les permitía recrear la primacía de los lazos familiares dentro de la congregación, dado que allí no eran un individuo, sino el representante del grupo doméstico. De este modo, los conflictos no emergían como resultado de una personalidad problemática en el seno de la congregación, sino como el efecto de la rivalidad entre familias. Estas rivalidades llevaban a que los jóvenes desconfiaran de la sinceridad de los adultos, dado que estos protegían a quienes cometían pecados.

Conforme al relato de los misioneros la base de las nuevas congregaciones no era la diversidad de interpretaciones de la palabra, como era habitual en el protestantismo europeo o americano, sino el mero conflicto de intereses entre los caciques y sus familias. Sin embargo, la emergencia de nuevas modalidades de liderazgo crítico entre los jóvenes, que utilizaban el texto Bíblico o los Evangelios para proponer cambios, era un problema para la congregación. Desde el punto de vista de

\footnotetext{
18 "Fallas" o "caídas" refieren a conductas reprobadas en las congregaciones, por ejemplo, beber alcohol, golpear a las esposas y a los hijos en estados de ebriedad, adulterio y faltas de respeto a la autoridad, entre otras.
}

los misioneros, estas prácticas culturales y las relaciones de rivalidad de las cuales estas dependen cuestionaban los conceptos de autoridad y de responsabilidad individual que los misioneros querían implantar. En Humahuaca, la feligresía no se acercaba al bautismo para mostrar su autonomía frente a su familia y frente a las tradiciones. Por el contrario, se acercaban para regenerar sus vínculos familiares y para restablecer rivalidades entre familias y entre congregaciones.

Los pastores combinan la formación religiosa con actividades deportivas, campamentos, viajes y encuentros destinados a los jóvenes de todo el país. Una tarde, después de una reunión de jóvenes, comencé a conversar con las jóvenes entre 16 y 25 años de edad, estudiantes, esposas, madres y comerciantes del centro de la ciudad. Rechazaban a la sociedad católica local, porque fomentaba la borrachera, el adulterio, la vagancia y la hipocresía y contrastaban este estado de cosas con los logros de la congregación bautista.

Lina había transgredido las costumbres religiosas de sus padres. Durante su niñez había asistido a misa y al catecismo, pero allí se sentía "vacía". Algunas lecturas de la catequesis le resultaron sugerentes pero los sacerdotes no hablaban con soltura sobre los problemas "del mundo", el adulterio, las adicciones, la violencia, los hijos no deseados. Una compañera de la escuela la invitó a asistir a las reuniones de la Iglesia Bautista "en secreto". En las reuniones se oraba, se leía y se comentaba la palabra y las personas hablaban de los problemas personales con soltura y ella se sentía "llena espiritualmente".

La satisfacción espiritual permite a las jóvenes y a los jóvenes bautistas superar las tensiones que produce la competencia sexual durante el período de búsqueda de pareja. A diferencia de los católicos que utilizan ropas y calzados específicos, salen a bailar, beben y suelen perder el tiempo en la escuela, la juventud bautista asiste a la escuela, trabaja y estudia de forma relajada porque la Iglesia les proporciona un soporte emocional a través de encuentros periódicos y de salidas a campamentos en los cuales los jóvenes saben que no deberán "aparentar", es decir, utilizar ciertos símbolos de consumo para resultar atractivos.

Frente a sus compañeras de escuela, las jóvenes creyentes eran personas responsables. Las jóve- 
nes católicas se distraían, hablaban y perdían el tiempo, es decir, se involucraban con varones, mientras las jóvenes creyentes llevaban una vida ordenada y relajada. En los campamentos organizados por la Iglesia Bautista, los jóvenes se encontraban, estudiaban juntos la Biblia, hacían juegos y caminatas y aprendían normas sobre cómo conducirse en el hogar. Se habla claramente sobre las responsabilidades mutuas que una relación de pareja supone. Las mujeres bautistas encontraron en la Congregación lo que buscaban “...una mujer busca amparo, protección y esa confianza, si no es creyente (el varón) yo no sé cómo será y ¿si después no puedo dominarlo?...”.

Si bien alguna de ellas no terminó la escuela secundaria, recuerdan que frente a la decisión de formar una pareja y/o de tener hijos, recibieron soporte de sus padres y de los miembros de la congregación. En las situaciones en las cuales las jóvenes estaban embarazadas, los varones estaban obligados a dar testimonio de su responsabilidad y la familia del varón se comprometía a contribuir con la crianza del bebé, pero no con la continuidad de la pareja, ya que conforme a la interpretación local del Evangelio, dependía del entendimiento y en definitiva de la voluntad de Dios que se mantuvieran juntos: "si se mantienen juntos será porque Dios lo quiso y si no no será".

Los jóvenes se quejan de la "ausencia de líderes" en la Congregación. Antiguamente los pastores funcionaban como modelos de autoridad y de responsabilidad y si algún hermano "caía" o "fallaba" (asistía a fiestas o bebía alcohol) los misioneros lograban bajar las tensiones emergentes en la familia y en la congregación a través del testimonio y de la oración. De este modo el "hermano", su familia y la congregación quedaban liberadas del pecado y de la posibilidad de repetición. Pero desde que los pastores no llegaban a Humahuaca y la Iglesia estaba en manos de los ancianos, las costumbres habían cambiado. Los ancianos solían hacerse mutuas acusaciones de "caídas", es decir, solían beber y con ello la feligresía perdía la confianza en que realmente la "voz del cristiano" fuera la "voz de Dios" guiando a la Congregación a buen destino. La razón de las "caídas" residía en que los ancianos habían tomado el Evangelio y lo habían adaptado a sus costumbres y por esta razón la comunidad no era realmente "salva". Esta situación había dado lugar a una crisis de autoridad en la Iglesia, ya que ningún anciano podía reclamar el "respeto" de sus esposas, de los miembros de la congregación y sobre todo de las nuevas generaciones, porque todos sabían que ellos no eran "santos".

Lalo formaba parte de una familia bautista. Dado que se sentía atraído por las fiestas y bebía con amigos, decidió apartarse del grupo juvenil. Al igual que otros jóvenes él esperaba conductas similares de los ancianos que lideraban la Iglesia. Desde el punto de vista de los jóvenes, los ancianos no respondían a las expectativas de conducta de un auténtico creyente y esta diferencia cuestionaba no sólo la identificación de las personas como cristianas, sino su propia honestidad frente a Dios y frente al resto de los humahuaqueños.

Además de la imposibilidad de ruptura con las tradiciones locales, vinculadas a la fiesta y a la violencia, la crisis de autoridad reinante en la congregación era producto de otras cuestiones. Por un lado, ni los sacerdotes católicos ni los pastores bautistas habían conseguido transmitir a la gente el misterio del Evangelio. Tanto la Iglesia Católica como la Iglesia Bautista norteamericana habían enviado misioneros y dinero a la región, pero no les habían transferido el misterio. Mientras los misioneros católicos aceptaban el sincretismo de costumbres, los misioneros bautistas las rechazaban. Sin embargo, el resultado de ello no fue el aprendizaje del Evangelio. La prueba estaba en que la gente no había transformado sus vidas, sino que había adaptado el Evangelio a sus costumbres. ¿Pero entonces si no venían a cambiar nada y si venían a transformar pero no transformaban, a qué venían los misioneros?

“...Dónde está la enseñanza que van a dejar acá, o qué han querido ellos llevar de nosotros? Si vos te remontas un poquito a la historia del catolicismo ¿Adónde han venido? A llevar la vida nuestra, las cosas de la zona y nada más. ¿Si vos te remontas ahí no más en Roma, las Cruzadas y todo eso, la Guerra Santa, hicieron de las suyas, hicieron un imperio que hoy es la Santa Sede económica y quién les para a ellos? Yo no sé qué beneficio ven ellos acá. No sé, o vinieron solamente a difundir el Evangelio y se fueron, no sé. Aparte de eso con toda la plata que han mandado, han sostenido a los pastores. Porque yo creo que acá se amoldó la escritura a la vida nuestra, a la vida de la gente. Y creo que esa no es la salvación, no es el mensaje que Dios dio, porque 
el mensaje que Dios dio es de transformación de tu vida..." (Abel, Humahuaca, 1995).

Finalmente, desde el punto de vista de Abel, dado que la reforma favorecía la "...libre interpretación de la Biblia..." y no conformaba un poder central visible, esto favorecía la emergencia de nuevos agrupamientos, como los bautistas renovadores y los pentecostales identificados con el movimiento de Renovación Carismática en la región.

\section{Conclusiones}

He argumentado que el discurso religioso de las Comunidades Eclesiales de Base católicas es un discurso equívoco para los jóvenes. Por un lado, los sacerdotes intentan promover actitudes maduras en los jóvenes a partir del estudio, la solidaridad y la reafirmación de los lazos familiares y de aquellos que los vinculan a sus ancestros y sus raíces indígenas. Pero, al mismo tiempo, reclaman actitudes íntimas de distancia, moderación y control. Esto lleva a que sean los jóvenes que pueden moverse exitosamente entre estas contradicciones, quienes participan de las CEBs pero creando la paradoja de que ellos no afirman una cultura indígena propia y compartida por el hecho de participar de las CEBs. Justamente la participación en las CEBs les permite negociar o negar su participación en una cultura indígenacampesina y recrearse a sí mismos en el contexto de una sociedad en la cual el bienestar está relacionado al ascenso social, al nivel de escolaridad $\mathrm{y}$ al establecimiento de relaciones políticas clientelares.

En contraste con el discurso de las CEBs, la participación en una religiosidad espiritual e intimista de las congregaciones bautistas permite a los adultos reconstituir lazos familiares dañados por el consumo excesivo, las adicciones y la violencia doméstica. La reconstitución de los lazos familiares se fortalece a través de desplazar las tensiones existentes entre las personas de la esfera individual y doméstica hacia la esfera de la sociedad local. Esto permite a los jóvenes establecer relaciones relajadas dentro sus hogares y dentro de las congregaciones y tomar distancia de la sociedad local. Sin embargo, ello no supone que las discontinuidades con la sociedad local son totales, sino que los efectos del ascenso y del descenso social permanecen bajo control.

Finalmente, la mayor parte de los jóvenes humahuaqueños permanece ajena a los nuevos movimientos religiosos o sólo se acerca a ellos para satisfacer convenciones sociales y criticar aquello que ven como parte del simulacro que impone la sociabilidad a los adultos. Esto no supone que no se inserten en las tradiciones religiosas de sus antepasados indígenas y en las cristianas, sino la conformación de nuevos modelos de liderazgo en los cuales los discursos y las prácticas religiosas continúan ofreciendo símbolos y significados que permiten procesar la experiencia. En Humahuaca este liderazgo encontraba su soporte institucional en el movimiento de la Renovación Carismática, tanto católico como bautista.

Agradecimientos Agradezco especialmente la colaboración del personal de ambas misiones y de los feligreses. Asimismo, agradezco al Consejo Nacional de Investigaciones Científicas y Técnicas y al Servicio Alemán de Intercambio Académico (DAAD) el soporte financiero para llevar adelante la investigación.

\section{REFERENCIAS CITADAS}

BRUSCO, E., 1995. Reformation of machismo: Evangelical conversion and gender in Colombia. University of Texas Press, Texas.

BURDICK, J., 1992. Rethinking the studies of social movements: The case of Christian Base Communities in urban Brazil. En The making of social movements in Latin America. Identity, strategy, and democracy, S. Alvarez y A. Escobar (Ed.), pp. 171-184. Westview Press, Boulder.
_- 1993. Looking for God in Brazil. The Progressive Catholic Church in urban Brazil religious arena. University of California Press, London, Berkeley, Los Angeles.

CANCLINI, A., 1981, Un hombre un pueblo, los bautistas argentinos a 100 años de la llegada de Pablo Besson. Asociación Argentina de Publicaciones, Buenos Aires. 
COMAROFF, J. y J. COMAROFF, 1993. Modernity and its cultural malcontents: Ritual and power in postcolonial Africa. Chicago University Press, Chicago.

FORNI, F., 1989. Derechos humanos y trabajo de base. Revista Sociedad y Religión 7: 46-57.

GEROW, C., 1997. Ms. Excerpts.

GÖBEL, B., 1999. Why herd animals die. Environmental perceptions and cultural risk management in the Andes. En Coping with changing environments. Social dimensions of endangered ecosystems in the developing world, B. Lohnert y H. Geist (Eds.), pp. 205-229 Ashgate Publishing Ltd., England y U.S.A.

HARRIS, O. y T. BOUYSSE-CASSAGNE, 1988. Pacha: En torno al pensamiento aymara. En Raíces de América. El mundo aymara, X. Albó (Ed.), pp. 217-281. Alianza, Madrid.

HARVEY, P., 1993. Género, comunidad y confrontación. Relaciones de poder en la embriaguez en Ocongate, Perú. En Borracheras y memoria. La experiencia de lo sagrado en los Andes, T. Saignes (Ed.), pp. 113-136. Hisbol / IFEA, Lima.

IRLAN, R., 1992. The kingdoms come. Religion and politics in Brazil. Pittsburgh University Press, Pittsburg.

ISLA, A., 1992. Dos regiones un origen. Entre el silencio y la furia. En Sociedad y articulación en las Tierras Altas Jujeñas. Crisis terminal de un modelo de desarrollo, A. Isla (Ed.), pp. 169-215. MLAL, U.B.A., Buenos Aires.

LOZANO, C., 2001. Misiones cristianas y población con raices indígenas: Un debate sobre la identidad y sobre las diferencias en el Noroeste Argentino. Wissenschftlicher Verlag Berlin.

LYNCH, J., 1986. Catholic Church in Latin America. En The Cambridge history of Latin America, L. Bethell (Ed.), vol. IV, pp. 527-595. Cambridge University Press, Cambridge.
MERLINO, R. y M. RABEY, 1993. Resistencia y hegemonía: Cultos locales y religión centralizada en los Andes del sur. Sociedad y Religión 10/11: 113-127.

MISION BAUTISTA CONSERVADORA, s/f Ms. Missionaries in Argentina, tell it like it is. A paper for the Orientation of Prospective Candidates. Informe manuscrito.

OLMEDO, J., 1994. Claretianos y la lucha por la justicia en la Prelatura de Humahuaca. Editorial Color Efe, Buenos Aires.

PLATT, T., 1976. Espejos y maíz: Temas de la estructura simbólica andina. Cipca, La Paz.

1997. Los guerreros de Cristo. Cofradías, misa solar, y guerra regenerativa en una doctrina Macha (siglos XVIII$X X)$. Asur y Plural Editores, La Paz.

SAIGNES, T., 1993. Borracheras y memoria. La experiencia de lo sagrado en los Andes. Hisbol / IFEA, Lima.

SHELLEY, B., 1973. What a baptist believe. Churchmart Editors, Wheaton, Illinois.

STOLL, D. y V. BRUNETT, 1993. Rethinking Pentecostalism in Latin America. Temple University Press, Philadelphia.

STRÖBELE-GREGOR, J., 1989. Indios de piel blanca: Evangelistas fundamentalistas en Chiquiyagu. Hisbol, La Paz.

VERGARA, M. A., 1942. Historia eclesiástica de Jujuy. Instituto de San Felipe y Santiago de Estudios Históricos de Salta, Del Consejo Consultivo del Instituto de Historia, Lingüística y Folklore de la Universidad Nacional de Tucumán.

WARDIN, A. 1995. Baptist around the world. A comprehensive handbook Broadman \& Holman Publishers. Nashville, Tennessee.

ZURETTI, J. C., 1955. Historia eclesiástica argentina. Editorial Huarpes, Buenos Aires.

_ 1972. Nueva historia eclesiástica argentina. Editorial Itinerarium, Buenos Aires. 